Abstracta Iranica Abstracta Iranica

Revue bibliographique pour le domaine irano-aryen

Volume 25 | 2004

Comptes rendus des publications de 2002

\title{
"Une résidence parthe dans le quartier nord de la ville royale de Suse ». Akkadica 123, 2, (2002),
} pp. 183-189.

Rémy Boucharlat

\section{(2) OpenEdition}

Journals

Édition électronique

URL : http://journals.openedition.org/abstractairanica/4351

DOI : 10.4000/abstractairanica.4351

ISSN : 1961-960X

Éditeur :

CNRS (UMR 7528 Mondes iraniens et indiens), Éditions de l'IFRI

\section{Édition imprimée}

Date de publication : 15 mai 2004

ISSN : 0240-8910

Référence électronique

Rémy Boucharlat, « "Une résidence parthe dans le quartier nord de la ville royale de Suse ». Akkadica 123, 2, (2002), pp. 183-189. », Abstracta Iranica [En ligne], Volume 25 | 2004, document 96, mis en ligne le 15 mars 2006, consulté le 25 septembre 2020. URL : http://journals.openedition.org/ abstractairanica/4351 ; DOI : https://doi.org/10.4000/abstractairanica.4351

Ce document a été généré automatiquement le 25 septembre 2020.

Tous droits réservés 


\section{«Une résidence parthe dans le quartier nord de la ville royale de Suse ». Akkadica 123, 2, (2002), pp. 183-189.}

\section{Rémy Boucharlat}

L'A. revient sur un monument daté par R. Ghirshman du $3^{\mathrm{e}}-4^{\mathrm{e}} \mathrm{s}$. de l'ère chrétienne et l'attribue au $2^{\mathrm{e}} \mathrm{s}$. sur la base de la céramique associée. C'est une résidence à grande salle tétrastyle décorée de fresques, et non un mithraeum comme Ghirshman l'avait pensé un temps. Gasche saisit cette occasion pour évoquer la question du plan de ces grandes résidences pour lesquelles il refuse un schéma diffusionniste simplificateur. À noter la qualité des plans bien meilleure que dans Steve et al. (c.r. ${ }^{\circ} 59$ ).

\section{INDEX}

Thèmes : 3.2.3. Séleucides, Parthes et Sassanides

\section{AUTEURS}

RÉMY BOUCHARLAT

CNRS - Lyon 